\title{
EVALUATING OPERATIONAL COMPETENCIES AND THE SUCCESS OF AGRICULTURAL COOPERATIVES IN SOUTH AFRICA
}

\author{
Tarisai F. Rukuni', Tendai Huni², Peter Tshetu ${ }^{3}$, Isah Leontes ${ }^{4}$, \& Elizabeth Takura ${ }^{5}$
}

\begin{abstract}
:
After gaining political independence, most African countries have persistently faced slow to negative economic growth. The economic growth rate for South Africa (SA) for the first quarter of 2018 was $1.5 \%$ and the unemployment rate at $26.7 \%$. Negative economic growth leads to a reduction in revenue, loss of employment, decrease in income and an increase in poverty. This study assesses the factors affecting the success of agricultural cooperatives in the City of Tshwane. A survey used self-completion questionnaire to collect data from 240 members of agricultural cooperatives located in the City of Tshwane, South Africa. Data analysis used Statistical Package for Social Sciences to conduct descriptive and multivariate analyses, factor analysis and correlations. Findings indicated that members of cooperatives had negative perceptions on operational competencies such as member participation, structural factors, communication, management, training and education, as well as on external factors at the agricultural cooperatives. It needs to be highlighted that operational competencies within the agricultural cooperatives affect the success of these cooperatives. The study recommendation includes the need for training and development for members, creation of sustainable relationships, networks with non-governmental organisations and external stakeholders, development of viable marketing strategies, and upgrading and improving of the infrastructure.
\end{abstract}

Keywords: Agricultural cooperative success, operational competencies, sustainability

\section{Introduction}

Post-independence African states have largely depended on the agriculture sector for national consumption and export earnings. However, most of these countries have persistently experienced a declining agricultural output, which has precipitated negative economic growth rates (Dejene \& Getachew, 2015). Such a feature has been a common phenomenon in South Africa (SA), whose economic growth was recorded at 1.5\% (National Treasury SA, 2018) and their unemployment rate was $26.7 \%$ in the first quarter of 2018 (Stats SA, 2018:1). According to Dejene and Getachew (2015), negative economic growth results in a reduction in revenue, loss of employment, decrease in income and increase in poverty. Slow economic growth should be worrying to the management of agricultural cooperatives. Researchers in contemporary economics (Dejene \& Getachew, 2015; Earl and Wakeley, 2005) argue that an assessment of factors affecting the success of agricultural cooperatives, is among one of the strategies that could be employed to protect agrarian organisations from succumbing to economic pressure. Consequently, the knowledge gained from the assessment of agricultural cooperatives, leads to an improvement of organisational operations (Amini \& Ramezani, 2016).

\footnotetext{
${ }^{1}$ University of the Free State; rukunitf@ufs.ac.za

2Pearson Institute of Higher Education; tendai.huni@pearson.com

${ }^{3}$ Pearson Institute of Higher Education; peter.tshetu@pearson.com

4Pearson Institute of Higher Education; isah.leontes@pearson.com

5Pearson Institute of Higher Education; elizabeth.takura@pearson.com
} 


\section{Background}

The economic stagnation of the country has serious negative repercussions on various sectors of the economy (Amini \& Ramezani, 2016). South Africa is one of the economies facing challenges of slow economic growth, as evidenced by the 1.5\% growth in the first quarter of 2018 (National Treasury SA, 2018; Stats SA, 2018). This has negative consequences on the operations of agricultural cooperatives. A slow-growing economy results in a decrease in the revenue and a loss of operational effectiveness and efficiency (Mala, 2018). Slow economic growth is threatening the survival of agricultural cooperatives that should be contributing to employment provision and poverty alleviation. An assessment of operational competencies in agricultural cooperatives is one of the strategies that can be employed to retain the competitiveness of the agricultural cooperatives. Based on this background, the objectives of this paper are twofold: (i) assess the perceptions of cooperative members on operational competencies of the agricultural cooperatives, and (ii) investigate the effect of operational competencies on the success of agricultural cooperatives. The formulated research question was: To what extent do operational competencies influence the success of agricultural cooperatives?

\section{Literature review}

\section{Agricultural cooperative}

The concept of agricultural cooperatives is defined by Dejane and Getachew (2015) as an autonomous association of people who come together to achieve their social, economic and cultural aspirations in democratically controlled organisations. The International Cooperative Alliance (2017) describes an agricultural cooperative as a process of unifying farms that belong to smallholder farmers. According to Digby (2013), an agricultural cooperative is an establishment from which several farmers collude resources to ensure optimum productivity from their joint effort. The definitions of agricultural cooperative suggest that people should voluntarily come together, with a common vision to be achieved through agricultural operations (Dejane \& Getachew, 2015; Digby, 2013). The definition of agricultural cooperatives highlights the importance of establishing a larger scale operation that is jointly governed (Digby, 2013). Agricultural cooperatives seek to create operational leverage for their members through economies of scale.

\section{Agricultural cooperative success}

Every agricultural cooperative aims at achieving success for its members (Azadi \& Karami, 2010). According to Dejane and Getachew (2015), agricultural cooperative success is estimated through the cooperative's prolonged existence, business performance, profitability and the satisfaction that members obtain. Bruynis, Goldsmith, Hahn and Taylor (2017) allude that agricultural cooperative success is expressed through economic success indicators, for example achievement of profits and minimization of costs during the operations. Bruynis et al. (2017) add that successful agricultural cooperatives can compete with other cooperatives. The performance of successful cooperatives makes it possible to compete with private sector agricultural entities. Garnevska, Liu and Shadbolt (2011) posit that successful agricultural cooperatives should conduct organisational affairs democratically. Garnevska et al. (2011) also state that successful agricultural cooperatives are so transparent that they provide members with an opportunity to access organisational information, including financial records. The United Nations (UN) (2018) emphasises that the success of agricultural cooperative depends on sound financial management, marketing ability and good managerial planning. The success of an agricultural cooperative is attained through ensuring that operational competencies are aligned with organisational vision.

\section{Operational competencies}

The management of agricultural cooperatives should overcome inherent challenges within their organisations (Banaszak, 2013). Overcoming of these challenges enables the attainment of maximum benefits for agricultural cooperatives. Consequently, it is important to understand the operational competencies that lead to the success of agricultural competencies. Dejene and Getachew (2015) argue that agricultural competencies are assessed in terms of cooperative member participation, member commitment, structural factors, communication, managerial 
support, training and education and external factors. Banaszak (2013) argues that the success of agricultural cooperatives depends on operational competencies, such as leadership strength, group size, business relationship and member selection process. Each of the operational competencies is briefly discussed below.

\section{Member participation}

The productivity of the agricultural cooperative is determined by the participation of its members (Azadi \& Karami, 2010). Amini and Ramezani (2016) postulate that the success of agricultural cooperatives is significantly influenced by the participation of the members. Hakelius (2009) adds that the participation and commitment of cooperative members is an integral part of the agricultural cooperative success. It is also reported that the cooperative's social and economic achievement is realized through member participation and collaboration (Dejene \& Getachew, 2015). Azadi and Karami (2010) posit that the agricultural cooperative has the responsibility to ensure that member commitment and participation is maintained through satisfying their needs. Consequently, the cooperative leaders should understand the factors that influence member satisfaction.

Agricultural cooperative member participation is measured through their propensity to add value in cooperative meetings (Amini \& Ramezani, 2016). Members should also serve on committees and be involved in the recruitment of additional cooperative members. Ahn, Brada and Mendez (2017) state that members should be involved in technical training programmes and cooperate governance. An equal opportunity to vote, should also be provided for agricultural cooperative members (Azadi \& Karami, 2010).

\section{Structural factors}

Structural factors express the membership composition and positions within the cooperative (Ahn et al., 2017). According to Banaszak (2013), the structure of the cooperative shows how the organisation functions. Further aspects considered by the structure of the cooperative include the homogeneity of the members and the size of the member component (Dejene \& Getachew, 2015). The availability of suitable facilities and sharing of good practice among cooperatives, is also critical for the success of the establishment. Azadi and Karami (2010) argue that structure influences the success of agricultural cooperatives.

\section{Communication}

Good communication is important for the success of the agricultural cooperative as articulated by Azadi and Karami (2010). Communication should be orally and in writings (Banaszak, 2013). There must be clear articulation among both external and internal stakeholders in the cooperative. Members should receive timely and worthwhile communication on cooperative matters. Dejene and Getachew (2015) state that information such as member responsibilities and benefits should be communicated among cooperative members. It is also important to communicate information related to the industry and to market trends (Azadi \& Karami, 2010). Management should also ensure that communication is accurate and that regular feedback is provided.

\section{Managerial issues}

The agricultural cooperative needs to be under good management (Prakash, 2013). Several factors need to be considered for management to be regarded as effective and efficient. Amini and Ramezani (2016) argue that management should possess sound interpersonal skills. It is also critical that management presents a great understanding of the concept of a cooperative. Members of management should also show great interest, talent as well as general managerial skills in working in a cooperative (Prakash, 2013). Managers should be able to handle dysfunctional conflict and ensure the commitment of members. According to Amini and Ramezani (2016), experience and longevity of more than five years can critically influence the success of agricultural cooperatives. 


\section{External factors}

Cooperatives exist amidst many external factors (Azadi \& Karami, 2010). These factors present threats and opportunities to the organisation. According to Prakash (2013), external factors have a great influence on organisational success. External factors include the availability of a market for the cooperative produce, the number of existing cooperatives in the geographical area, and good infrastructural development. Amini and Ramezani (2016) add that external factors include the support that is received from the government and non-governmental organisations. The agricultural cooperatives should therefore ensure that operational competencies such as member participation, structural factors, communication, managerial influence, and external factors are understood (Dejene \& Getachew, 2015). These competencies are critical in determining the success of the agricultural cooperative (Amini \& Ramezani, 2016).

\section{Review of Empirical evidence}

Literature shows that research regarding agricultural operational competencies in the South African context, is in its infancy (Mala, 2018; Azadi \& Karami, 2010). Several researchers (Ahn et al., 2017; Dejane \& Getachew, 2015) provide insight into operational competencies within agricultural cooperatives. Amini and Ramezani (2016) carried out research in Iran within the Gholestan and Mazandaran province concerning the significance of member participation in the agricultural province. Results of the research (Amini \& Ramezani, 2016) indicated that member participation is the most critical competency that leads to the success of agricultural cooperatives. Other researchers such as Ahn et al. (2017), also carried out similar research, however, it was realised that member participation requires other competencies, such as the cooperative structure and managerial efficacy to produce success for the agricultural cooperative. In this study the researchers examined members' participation, as well as organisational structural aspects, and how they influenced the success of the cooperatives.

Dejene and Getachew (2015) and Banaszak (2013) reported that structural factors such as member composition and availability of structural facilities are critical in the determination of cooperative success. However, Mala (2018) presents findings that contradict Dejene and Getachew (2015) and Banaszak (2013), and reported that structural factors in isolation are not sufficient for the success of cooperatives. The divergent empirical evidence contributed to the objectives that supported this study on cooperatives in the City of Tshwane.

A study of Digby (2013) in India reported that communication is critical in ensuring the success of agricultural cooperatives. This finding is supported by Bruynis et al. (2017) and Barton, Boland, Chaddad and Eversull (2011), who established that written communication plays a critical role in the success of agricultural cooperative success. A study by Thornton et al. (2010) highlighted the role of managerial influence. They reported that managerial factors like good interpersonal skills, a good understanding of the concept of cooperatives, and interest to work in cooperatives, were important in achieving the success of a cooperative. Gabara (2013) reported that while communication is important, factors such as member commitment and managerial influence, are equally influential in determining the success of cooperatives.

A study by Banaszak (2013) in Poland, noted that external factors play a vital role in determining the success of cooperative success. Garnevska et al. (2011:69) examined the influence of external factors in North West China, and reported a significant influence of external factors on the operations of agricultural cooperatives.

Figure 1 shows the theoretical conceptual model depicting the key variables under consideration in this study.

\section{Theoretical Conceptual Model}

This study is grounded on the operational competencies and agricultural cooperative success theory (Banaszak, 2013:133). The study's conceptual framework identifies operational competencies that have been highlighted in the literature, specifically, cooperative member participation, member commitment, structural factors, communication, managerial support, training and education, as well as external factors. 


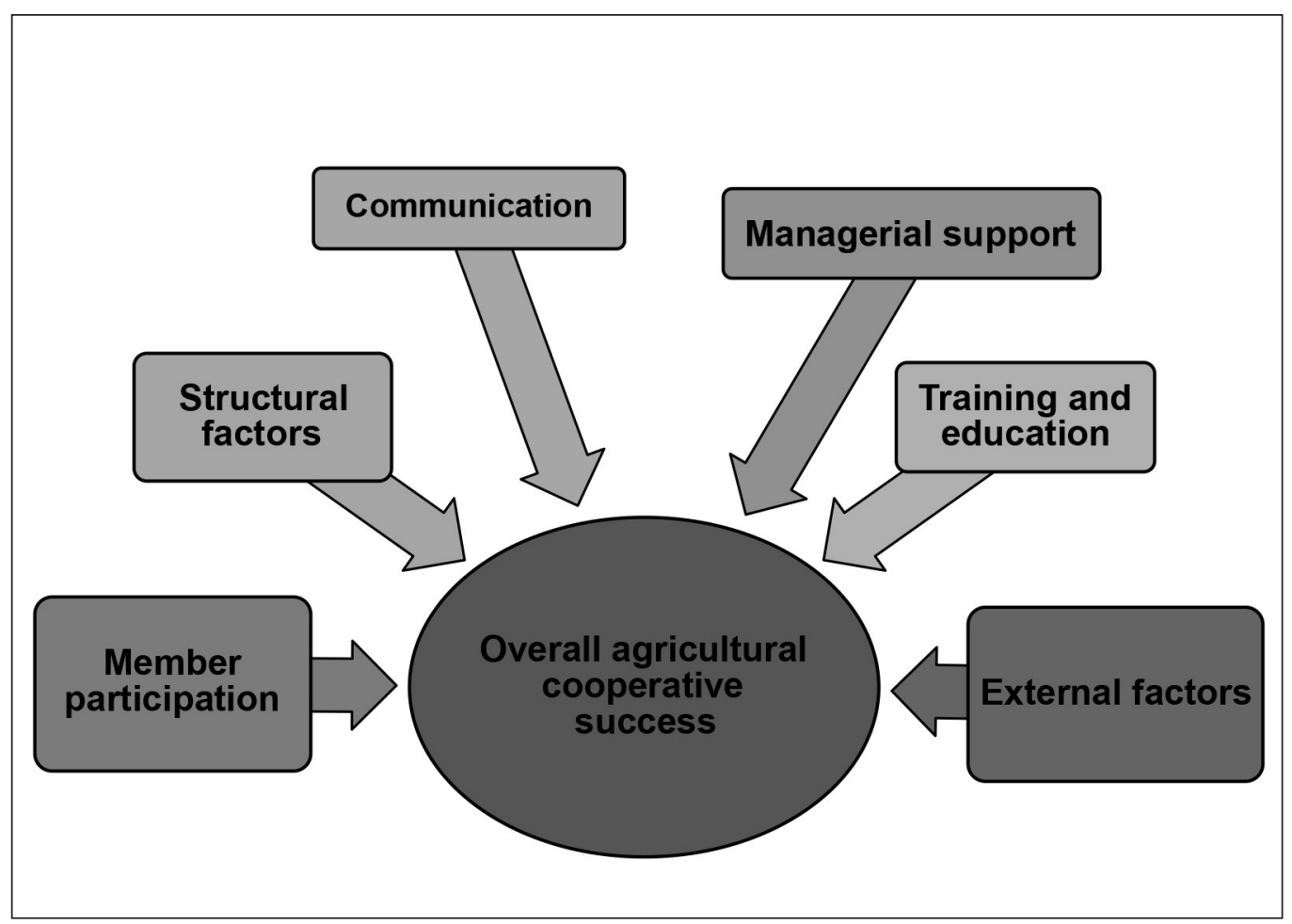

Source: Adapted from Banaszak (2013) and Dejene and Getachew, 2015:9

\section{Research hypotheses}

H1: $\quad$ Member participation has an effect on overall agricultural cooperative success.

H2: $\quad$ Structural factors have an effect on overall agricultural cooperative success.

H3: $\quad$ Communication has an effect on overall agricultural cooperative success.

H4: Management has an effect on overall agricultural cooperative success.

H5: $\quad$ Training and education has an effect on overall agricultural cooperative success.

H6: External factors have an effect on overall agricultural cooperative success.

\section{Research methodology}

This study adopted a quantitative research approach. A survey design used a self-administered questionnaire developed from literature (Dejene \& Getachew, 2015:9) to collect the data. A pilot study was conducted to assess the validity and reliability. The study population comprised 92 agricultural cooperatives with approximately 600 members in the City of Tshwane (National Cooperative Business Association, 2018). Stratified and convenience sampling strategy was employed to select three members from each cooperative. A study sample of two-hundred and forty (240) was selected, based on the Slovin's Formula (Tejada \& Punzalan, 2012:129) with a 95\% confidence level and a 5\% degree of error. SPSS was employed to conduct descriptive and multivariate analyses, including correlations and regression analyses. Further tests of validity and reliability were conducted, using factor analysis and Cronbach's alpha, respectively.

\section{Results}

\section{Members' perceptions on the operational competencies}

The first objective in this study sought to assess the perceptions of cooperative members on operational competencies of the agricultural cooperative. The objective was operationalised, using mean and standard deviation. Operational competencies included member participation, structural factors, communication, management, training and education, and external factors. A 5-point Likert scale (strongly agree $=1$; strongly disagree $=5$ ) was also employed to measure the perceptions of cooperative members on operational competencies. The findings of these perceptions are presented in Table 1. 
Table 1: Agricultural cooperative members' perception on agricultural operational competencies $(n=240)$

\begin{tabular}{|c|c|c|c|}
\hline & Dimensions and items & Mean & Standard deviation \\
\hline & Member participation & 2.22 & 1.18 \\
\hline MP1 & Participate in all meetings of the cooperative & 2.23 & 1.19 \\
\hline MP2 & Serve on the committee of the cooperative & 2.23 & 1.14 \\
\hline MP3 & Involved during the recruitment of additional members & 2.43 & 1.18 \\
\hline MP4 & Participate during voting processes in meetings & 2.08 & 1.21 \\
\hline \multirow[t]{2}{*}{ MP5 } & Participate during technical training offered by the cooperative & 2.17 & 1.18 \\
\hline & Structural factors & 2.36 & 1.03 \\
\hline SF1 & Cooperative members possess different skills and think differently & 1.79 & 0.91 \\
\hline SF2 & The cooperative has well-structured facilities & 2.74 & 1.09 \\
\hline SF3 & Cooperative share successful practice with other cooperatives & 2.54 & 1.09 \\
\hline \multirow[t]{2}{*}{ SF4 } & The cooperative has a good relationship with other cooperatives & 2.39 & 1.03 \\
\hline & Communication & 2.21 & 1.06 \\
\hline C1 & Members have access to timely and worthwhile information & 2.21 & 1.05 \\
\hline $\mathrm{C} 2$ & Clear communication of member-owner responsibilities & 2.08 & 0.99 \\
\hline $\mathrm{C} 3$ & Communication of related industry news and market trends & 2.40 & 1.12 \\
\hline C4 & Accuracy of messages cooperatives communicate to the member & 2.31 & 1.10 \\
\hline C5 & Provision of regular feedback to members & 2.14 & 1.05 \\
\hline \multirow[t]{2}{*}{$\mathrm{C} 6$} & Good communication medium & 2.16 & 1.08 \\
\hline & Management & 2.06 & 0.94 \\
\hline GM1 & Having good interpersonal skills & 1.91 & 0.90 \\
\hline GM2 & Having a good understanding of the concept of cooperatives & 2.10 & 0.95 \\
\hline GM3 & Show good interest to work in cooperatives & 1.95 & 0.86 \\
\hline GM4 & Having good experience of working in cooperatives & 2.10 & 0.96 \\
\hline \multirow[t]{2}{*}{ GM5 } & Having efficient conflict solving abilities & 2.28 & 1.04 \\
\hline & Training and education & 2.39 & 1.42 \\
\hline TE1 & Cooperative members receive regular internal training & 2.41 & 1.18 \\
\hline TE2 & Cooperative members are provided with external training & 2.65 & 1.20 \\
\hline TE3 & Internal training received is helpful in developing skills & 2.19 & 1.01 \\
\hline \multirow[t]{2}{*}{ TE4 } & External training received add value to cooperative activities & 2.32 & 2.32 \\
\hline & External factors & 3.04 & 1.08 \\
\hline E1 & The cooperative has a good access to the market & 2.99 & 1.15 \\
\hline E2 & The area has few cooperatives existing & 2.74 & 1.07 \\
\hline E3 & The area has a good infrastructure development (i.e. good road network) & 3.12 & 1.10 \\
\hline E4 & The government is strongly supportive of the operations of the cooperative & 3.12 & 1.10 \\
\hline \multirow[t]{2}{*}{ E5 } & There is support from non-government organisations & 3.25 & 1.02 \\
\hline & Overall agricultural cooperative success & & \\
\hline CS1 & General satisfaction with the operations of the cooperative & 2.25 & 1.06 \\
\hline CS2 & General business growth is expected from the cooperative & 2.07 & 0.97 \\
\hline CS3 & General longevity is expected from the cooperative & 2.10 & 1.07 \\
\hline CS4 & The cooperative is able to meet its objectives. & 2.29 & 1.13 \\
\hline
\end{tabular}


In this research, the mean value 1.0-2.0 represented positive perceptions on operational competencies of the agricultural cooperative and the mean value 2.1-5.0 signified negative perceptions. It was found that cooperative members had negative perceptions of operational competencies for the agricultural cooperatives sampled in this study. This finding was evidenced by the mean values of the operational competencies' sub-constructs that were ranged from 2.1-5.0. The results indicated that agricultural cooperative members had negative perceptions about: member participation as evidenced by a mean value of 2.22; structural factors as evidenced by the mean value of 2.36; communication within the agricultural cooperatives and this was evidenced by the mean value of 2.21 ; management style in the agricultural cooperative as indicated by the mean value of 2.06; training and education effort put in the agricultural cooperatives evidenced by the mean value of 2.39; external factors influencing the operations of the agricultural cooperatives, evidenced by the mean value of 3.04 .

\section{Validity and reliability analysis}

The second objective in this study aimed to investigate the effect of operational competencies on the success of agricultural cooperatives. This object required the use of inferential analysis such as correlation and regression analysis (Saunders, et al., 2012). It is also important to note that the reliability and validity of the data is a prerequisite for correlation and regression to be carried out. The reliability of the data was tested using Cronbach's Alpha, while the validity was measured using factor analysis as shown in Table 2.

Table 2: Validity and reliability of the 29 items for operational competencies

\begin{tabular}{|c|c|c|c|c|c|c|c|}
\hline \multicolumn{8}{|c|}{ FACTORS } \\
\hline & 1 & 2 & 3 & 4 & 5 & 6 & 7 \\
\hline MP1 & .66 & & & & & & \\
\hline MP2 & .63 & & & & & & \\
\hline MP3 & .66 & & & & & & \\
\hline MP4 & .73 & & & & & & \\
\hline MP5 & .59 & & & & & & \\
\hline SF1 & & .53 & & & & & \\
\hline SF2 & & .39 & & & & & \\
\hline SF3 & & .52 & & & & & \\
\hline SF4 & & .52 & & & & & \\
\hline C1 & & & .70 & & & & \\
\hline $\mathrm{C} 2$ & & & .73 & & & & \\
\hline $\mathrm{C} 3$ & & & .67 & & & & \\
\hline C4 & & & .75 & & & & \\
\hline C5 & & & .71 & & & & \\
\hline $\mathrm{C} 6$ & & & .76 & & & & \\
\hline $\mathrm{M} 1$ & & & & .67 & & & \\
\hline $\mathrm{M} 2$ & & & & .72 & & & \\
\hline M3 & & & & .65 & & & \\
\hline M4 & & & & .73 & & & \\
\hline M5 & & & & .67 & & & \\
\hline TE1 & & & & & .55 & & \\
\hline TE2 & & & & & .47 & & \\
\hline TE3 & & & & & .49 & & \\
\hline TE4 & & & & & .46 & & \\
\hline
\end{tabular}




\begin{tabular}{|c|c|c|c|c|c|c|c|}
\hline E1 & & & & & & .49 & \\
\hline E2 & & & & & & .54 & \\
\hline E3 & & & & & & .43 & \\
\hline E4 & & & & & & .60 & \\
\hline E5 & & & & & & .58 & \\
\hline CS1 & & & & & & & .62 \\
\hline CS2 & & & & & & & .57 \\
\hline CS3 & & & & & & & .63 \\
\hline CS4 & & & & & & & .59 \\
\hline$\alpha$ & .92 & .76 & .93 & .92 & .92 & .85 & .91 \\
\hline
\end{tabular}

Reliability analysis was conducted on all the six operational competencies that include member participation, structural factors, communication, management, training and education and external factors. According to Field (2009), a threshold of 0.7 should be employed as a benchmark for sub-constructs to be regarded as reliable. In this study, it was found that all sub-constructs had a Cronbach's Alpha above 0.7, which is evidence of the reliability of the study. Malhotra (2010) argues that validity should be tested on the items that represent the sub-construct measured in the study. A minimum threshold of 0.4 should be reached for an item to be regarded as valid for further analysis (Field, 2009). It is important to note that in this study, all items except SF2, were found to have a factor value of 0.4 and above. SF2 was removed before correlation and regression were performed.

\section{Correlation analysis}

Considering that Objective 2 aimed at investigating the effect of operational competencies on the success of agricultural cooperatives, it was important to make use of correlation analysis. The correlation between subconstructs (operational competencies and overall agricultural cooperative success) was measured through the Pearson coefficient ( $r$-value) and the probability value ( $p$-value). The $r$-value measures the strength of the relationship between two or more constructs. The r-value is also measured by a value that ranges from -1 to 1 . A negative 1 means that there is a perfect negative relationship between two or more constructs, and a positive 1 means that there is a perfect positive relationship between two or more constructs. The p-value measures the statistical significance of the obtained results. Statistically significant results should have a p-value that is 0.05 or less. Table 3 illustrates correlations results.

Table 3: Correlation analysis Dependent construct: Overall agricultural cooperative success

\begin{tabular}{|c|c|c|c|c|c|c|c|}
\hline & & 1 & 2 & 3 & 4 & 5 & 6 \\
\hline 1 & Member participation & 1 & & & & & \\
\hline 2 & Structural factors & $.51 *$ & 1 & & & & \\
\hline 3 & Communication & $.67^{*}$ & $.39 *$ & 1 & & & \\
\hline 4 & Management & $.48^{*}$ & $.54^{\star}$ & $.48^{\star}$ & & & \\
\hline 5 & Training and education & $.30 *$ & $.32^{\star}$ & $.32^{\star}$ & $.46^{\star}$ & 1 & \\
\hline 6 & External factors & $.31 *$ & $.27^{\star}$ & $.49 *$ & $.39 *$ & $.39 *$ & 1 \\
\hline 7 & Overall agricultural cooperative success & $.31 *$ & $.38^{*}$ & $.51 *$ & $.12^{\star}$ & $.53^{*}$ & $.53^{*}$ \\
\hline
\end{tabular}

${ }^{*} p<.001 \quad$ Source: Researchers' own construct

The results indicate that there is a weak to moderate positive relationship among the sub-constructs that were tested in this study. The r-value for all the relationships tested, range between 0.12 to 0.67 . The findings were also statistically significant, given that the $p$-value was less than 0.05 for all relationships tested. After it was realised that correlation analysis was statistically significant, researchers proceeded with regression analysis. 


\section{Regression analysis and Hypotheses test}

Regression analysis was carried out in this study to test the formulated hypotheses. This study had a total of six hypotheses. Table 4 illustrates the results of the regression analysis. These results were employed to test the hypotheses as follows:

\section{Hypothesis 1}

Based on the findings presented in Table 4, Hypothesis 1 states that member participation has an effect on overall agricultural cooperative success is accepted at $p<0.001$ significant level. The results on regression analysis provided evidence that member participation had a moderate positive effect on overall agricultural cooperative success with an r-value $=0.31$ and a p-value $<0.001$ significant level. In a study carried out by Amini and Ramezani (2016) in Iran within the Gholestan and Mazandaran province, it was found that member participation is the most critical competency that leads to the success of agricultural cooperatives. Other researchers such as Ahn et al. (2017) also carried out similar research, however, it was realised that member participation requires other competencies, such as the cooperative structure and managerial efficac to produce success for the agricultural cooperative.

\section{Hypothesis 2}

The findings in the regression analysis were also employed to test Hypothesis 2 that states that structural factors have an effect on overall agricultural cooperative success. Hypothesis 2 is accepted at $p<0.001$ significant level. The results on regression analysis provide evidence that structural factors have an effect on overall agricultural cooperative success with an $r$-value $=0.38$ and a p-value $<0.001$ significant level. Dejene and Getachew (2015) and Banaszak (2013:48) also found that structural factors such as member composition and availability of structural facilities are critical in the determination of cooperative success. Mala (2018) disagrees with Dejene and Getachew (2015), as well as Banaszak (2013), and highlights that structural factors, in isolation, are not sufficient in producing cooperative success.

\section{Hypothesis 3}

Hypothesis 3 was formulated as communication that has an effect on overall agricultural cooperative success. The results in Table 4 provide evidence that communication has a moderate positive effect on overall agricultural cooperative success. This was evidenced by the r-value $=0.51$ and the $p$-value $<0.001$. Digby (2013) carried out a study in India and it was established that communication is critical in ensuring the success of the agricultural cooperative. This finding is also supported by Bruynis et al. (2017) and Barton et al. (2011) who established that written communication plays a critical role in the success of agricultural cooperative success.

\section{Hypothesis 4}

The findings in the regression analysis were also employed to test Hypothesis 4 that states that management has an effect on overall agricultural cooperative success. Hypothesis 4 is accepted at $p<0.001$ significant level. The results on regression analysis provide evidence that management has a moderate positive effect on overall agricultural cooperative success with an $r$-value $=0.55$ and a $p$-value $<0.001$ significant level. Dejene and Getachew (2015) and Banaszak (2013) also found that management of the agricultural cooperatives is critical in the determination of cooperative success. Mala (2018) opposes the findings of Dejene and Getachew (2015) as well as Banaszak (2013), with the results of the research that shows that management alone is not sufficient in producing cooperative success.

\section{Hypothesis 5}

Based on the findings presented in Table 4, Hypothesis 5 states that training and education has an effect on overall agricultural cooperative success, and is accepted at $p<0.001$ significant level. The results on regression analysis provided evidence that training and education has a weak positive effect on overall agricultural cooperative success with an $r$-value $=0.12$ and a p-value $<0.001$ significant level. In a study carried out by Amini and Ramezani (2016) in Iran within the Gholestan and Mazandaran province, it was found that training and education in cooperatives is the most critical competency that leads to the success of agricultural cooperatives. Other researchers such as Ahn et al. (2017) also carried out similar research, however, it was realised that training and education require other competencies, such as the cooperative structure and managerial efficacy to produce success for the agricultural cooperative. 


\section{Hypothesis 6}

Hypothesis 6 was formulated to assess the effect of external factors on the success of agricultural cooperatives. The results in Table 4 provide evidence that external factors had a moderate positive effect on overall agricultural cooperative success. This was evidenced by an $r$-value $=0.53$ and a $p$-value $<0.001$. Digby (2013) carried out a study in India and it was established that external factors are critical in ensuring the success of the agricultural cooperative. This supports Bruynis et al. (2017) and Barton et al. (2011) who reported that the role of external factors in the success of agricultural cooperatives.

Table 4: Regression analysis

Dependent variable: Overall agricultural cooperative success

\begin{tabular}{|c|c|c|c|c|c|c|c|}
\hline & B & SEB & $\beta$ & $T$ & Sig & $\mathbf{R}^{2}$ & Hypothesis \\
\hline $\begin{array}{c}\text { (Constant) } \\
\text { Perceived member } \\
\text { participation }\end{array}$ & $\begin{array}{c}6.16 \\
.23\end{array}$ & $\begin{array}{l}.69 \\
.06\end{array}$ & .31 & $\begin{array}{l}8.88 \\
4.04\end{array}$ & .000 & .10 & Accept H1 \\
\hline $\begin{array}{c}\text { (Constant) } \\
\text { Perceived structural } \\
\text { factor }\end{array}$ & $\begin{array}{c}4.37 \\
.46\end{array}$ & $\begin{array}{l}.89 \\
.09\end{array}$ & .38 & $\begin{array}{l}4.90 \\
5.14\end{array}$ & .000 & .15 & Accept H2 \\
\hline $\begin{array}{c}\text { (Constant) } \\
\text { Perceived } \\
\text { communication } \\
\end{array}$ & $\begin{array}{c}4.10 \\
.35\end{array}$ & $\begin{array}{l}.69 \\
.05\end{array}$ & .51 & $\begin{array}{l}5.96 \\
7.24\end{array}$ & .000 & .26 & Accept H3 \\
\hline $\begin{array}{c}\text { (Constant) } \\
\text { Perceived } \\
\text { management }\end{array}$ & $\begin{array}{c}3.51 \\
.50\end{array}$ & $\begin{array}{l}.69 \\
.06\end{array}$ & .55 & $\begin{array}{l}5.06 \\
8.05\end{array}$ & .000 & .30 & Accept H4 \\
\hline $\begin{array}{l}\text { (Constant) } \\
\text { Perceived training } \\
\text { and education }\end{array}$ & $\begin{array}{c}7.67 \\
, 11\end{array}$ & $\begin{array}{l}.77 \\
.07\end{array}$ & .12 & $\begin{array}{l}9.94 \\
1.46\end{array}$ & .000 & .01 & Accept H5 \\
\hline $\begin{array}{c}\text { (Constant) } \\
\text { Perceived external } \\
\text { factor }\end{array}$ & $\begin{array}{c}1.64 \\
.46\end{array}$ & $\begin{array}{l}.95 \\
.06\end{array}$ & .53 & $\begin{array}{l}1.73 \\
7.74\end{array}$ & .000 & .28 & Accept H6 \\
\hline
\end{tabular}

${ }^{*} p<0.001 ;{ }^{* *} p<0.17$

The hypotheses above are based on the results of the regression analysis conducted as shown in Table 4. Table 4 contains alpha and regression coefficients, where SEB is the standard error of the coefficient of determination, $\beta$ is the standardised beta coefficient, and $\mathrm{R}^{2}$ is the coefficient of determination as they were used to measure the explanatory power of predictor variables (operational competencies) to the dependent variable (overall agricultural cooperative success).

\section{Conclusions and Recommendations}

The objectives of this study were twofold: i) to assess the perceptions of cooperative members on operational competencies of the agricultural cooperative and ii) to investigate the effect of operational competencies on the success of the agricultural cooperative. The aim of the research study was to examine the extent which operational competencies influence the success of agricultural cooperatives. The study findings with respect to Objective (i), was that agricultural cooperative members had negative perceptions on operational competencies encompassing member participation, structural factors, communication, management, training and education, and external factors. Concerning Objective (ii), it was found that operational competencies that include member participation, structural factors, communication, management, training and education and external factors, had a positive effect on the success of agricultural cooperatives. It was also found that operational competencies influence the success of agricultural cooperatives at varying levels. Management had the highest explanatory power on the success of agricultural cooperatives, followed by external factors, communication, structural factors, member participation and training and education. 
The recommendations are as follows:

\section{Creating sustainable relationships with non-governmental organisations}

It is important for the agricultural cooperative to actively seek partnerships with non-governmental organisations who assist with the development of cooperatives. There are non-governmental organisations that specialise in assisting the development of the cooperative. It is important to identify non-governmental organisations that understand the impact that cooperatives have on economic development. Ultimately, a good relationship with non-governmental organisation assist in capacitating the operations of the agricultural cooperatives.

\section{Improving the infrastructure}

This research suggests that there is a shortage of infrastructure to support the operations of agricultural cooperatives. It is therefore important for the agricultural cooperatives and the local government to work together towards ensuring that sufficient infrastructure is put into place. It is important to ensure that the infrastructure such as accessible roads, and electricity and water, is put in place in the environment where agricultural cooperatives are operating. The duty to identify missing infrastructure should be given to the agricultural cooperatives, so that the right facilities could be put in place.

\section{Accessing markets}

There is a need to ensure that agricultural cooperatives have access to markets. Markets present an opportunity for agricultural cooperatives to sell their produce. It is, therefore, necessary for the agricultural cooperatives to work with the local government to ensure the establishment of markets. Designated places should be put in place to ensure that agricultural cooperatives can meet buyers of their produce.

\section{Training and development of cooperative members}

The management of the agricultural cooperative should ensure continuous improvement in work processes and systems. Such improvement can be achieved by ensuring that training is provided to employees. Thus, there is a need for the agricultural cooperative to provide both internal and external training to its members. There has to be a plan in place that directs the timelines when members are provided with the training.

\section{Implications for practice}

The findings in this study have shown that agricultural cooperative members had negative perceptions towards aspects such as the measure of support provided by non-government organisations, available infrastructure, government support, accessibility to markets, competition from existing cooperatives, facilities within the cooperative, cooperation among cooperatives, and training provided to cooperative members. Based on the findings of this study, several recommendations are provided to both management of the agricultural cooperatives and economic development policymakers within the government.

\section{Limitations of the study}

The study was done on a single agricultural cooperative. Thus, the opinions expressed are those of members within a single agricultural cooperative. The findings do not necessarily represent the situation in other agricultural cooperatives that were not considered in this study. It is also important to note that this study focused on an agricultural cooperative within the City of Tshwane and excluded agricultural cooperatives outside the City of Tshwane.

The research study adopted a quantitative research methodology, and did not make use of qualitative research methodology that permits the respondents to respond in their own words. Consequently, the sampled respondents were not allowed to respond to questions in their own words. This study only concentrated on a selected number of operational competencies (member participation, structural factors, communication, management, training and education and external factors) that were provided by the model that was adopted by the researcher. It is important to note that the operational competencies employed in this study, are not exhaustive of all the operational competencies within agricultural cooperatives. 


\section{Directions for future research}

Future researchers should conduct research in more than one agricultural cooperative. Further comparative studies should be undertaken by focusing on agricultural and non-agricultural cooperatives. Future researchers should also consider researching agricultural cooperatives that are located outside the City of Tshwane. It is also important that future researchers consider the use of qualitative research methodologies that enable the in-depth understanding of the phenomena. Future researchers could explore different operational competencies as well as the implications thereof for the success of agricultural cooperatives.

\section{References}

Ahn, S, C., Brada, J, C., \& Me' ndez, J, A. 2017. Effort, technology and the efficiency of agricultural cooperatives. Journal of Development Studies, 48(11): 1601-1616.

Amini, A. M., \& Ramezani, M. 2016. Study of effective factors on success of poultry-farm cooperatives in Gholestan and Mazandaran province. Journal of Agriculture Science \& Natural Resources, 13(2): 123 - 133.

Azadi, H. \& Karami, E. 2010. Comparison of mechanization unit of rural cooperatives, production cooperatives and mechanization companies in Fars province, Iran. Journal of Science \& Technology of Agriculture \& National Resources, 5(3): 33-48.

Banaszak, I. 2013. Determinants of successful cooperation in agricultural markets: evidence from producer groups in Poland. Strategy and governance of networks. Heidelberg: Physical-Verlag.

Barton, D., Boland, M., Chaddad, F., \& Eversull, E. 2011. Current challenges in financing agricultural cooperatives. Agricultural \& Applied Economics Association, 26(3).

Bruynis, C. L., Goldsmith, P. D., Hahn, D. E. \& Taylor, W. J. 2017. Key success factors for emerging agricultural marketing cooperatives. Journal of Cooperatives, 16: 19-24.

Dejene, E. \& Getachew, D. 2015. Factors affecting success of agricultural marketing cooperatives in Becho Woreda, Oromia regional State of Ethiopia. International Journal of Cooperative Studies, 4(1): 9-17.

Digby, M. S. 2013. Cooperative marketing in India. Review of International Cooperation, 69(2): 52-63.

Earl, P. \& Wakeley, T. I. 2005. Business economics: a contemporary approach. McGraw Hill Education.

Field, A. 2009. Discovering statistics using SPSS. 3rd ed. Thousand Oaks, CA: Sage.

Gabara, N. 2013. Farming cooperatives provides food and jobs. The Journal of Southern Africa, 10(13): 124 - 143.

Hakelius, K. 2009. Cooperative values-farmers' cooperatives in the minds of farmers. Dissertation, Swedish University of Agricultural sciences.

International Cooperative Alliance. 2017. International co-operatives research conference, statement on the cooperative identity. Geneva.

Garnevska, E., Liu, G \& Shadbolt, N. M. 2011. Factors for successful development of farmer cooperatives in Northwest China. International Food \& Agribusiness Management Review, 14(4): 69 - 84.

Mala, L. 2018. Sugar co-operatives in Maharashtra: A political economy perspective. The Journal of Development Studies, 44 (10): $1474-1505$.

Malhotra, N. 2010. Marketing research: an applied orientation. 6th ed. Upper Saddle River, NJ: Pearson. 
National Cooperative Business Association (NCBA). 2018. Liberation of agricultural cooperatives. NCBA [Online] Available from: http://www.ncba.org/ [Accessed 10/08/2018].

National Treasury, South Africa. 2018. Budget review. ISMB: 978-0-621-46020-9, pp, 1 - 299.

Prakash, D. 2013. Capacity building of agricultural cooperatives to meet the market and human resources development demands. A step-by-step approach participatory management development advisory network. New Delhi: India.

Saunders, M., Lewis, P. \& Thornhill, P. 2012. Research Methods for Business Students. $5^{\text {th }}$ Edition. Pearson Education Limited: England.

Statistics South Africa. 2018. Category archives: economic growth. Stats SA [Online] Available at: http://www. statssa.gov.za/?cat=30 [Accessed 14/07/2018].

Tejada, J. J. \& Punzalan, J. R. B. 2012. On the misuse of Slovin's formula. The Philippine Statistician, 61(1):129-136.

Thornton, A., Nel, E. \& Hampwaye, G. 2010. Cultivating Kaunda's plan for self-sufficiency: Is urban agriculture finally beginning to receive support in Zambia? Development Southern Africa, 27(4): 613 - 625.

United Nations (UN) 2018. Millennium development goals: Annual report. UN, New York. 